\title{
Bioextraction of Cu (II) Ions from Acid Mine Drainage by Bacillus Thuringiensis
}

\author{
Reza Marandi
}

Department of Environmental Engineering, Islamic Azad University, North Tehran Branch, Tehran, Iran

\begin{abstract}
In this study, biosorption of $\mathrm{Cu}$ and $\mathrm{Mn}$ ions from Sarcheshme copper mine wastewater by a locally available bacterium, Bacillus Thuringiensis, was investigated in batch mode. Optimum amounts for various parameters such as contact time, $\mathrm{pH}$, initial ion concentration, biosorbent dosage and temperature were determined. In the first 30 minutes, most of $\mathrm{Cu}$ and $\mathrm{Mn}$ ions were removed by the sorbent. Optimum $\mathrm{pH}$ and temperature were determined to be 6 and $308^{\circ} \mathrm{K}$. The experimental data were fitted to both Langmuir and Freundlich adsorption models. Desorption studies showed that bacterial biomass can be eluted by $1 \mathrm{M}$ HCL solution and reused in five biosorption-desorption cycles.
\end{abstract}

Keywords Biosorptoin, $\mathrm{Cu}$ and $\mathrm{Mn}$ ions, Bacillus Thuringiensis, Bioextraction, Acid Mine Drainage

\section{Introduction}

Heavy metal ions in wastewater cause serious problems on human health and environment. The main sources of these ions are mining and electroplating. $\mathrm{Cu}, \mathrm{Mn}, \mathrm{Pb}, \mathrm{Cr}, \mathrm{Zn}, \mathrm{Ni}$, $\mathrm{Cd}$ are some metals that these industries discharge into environment. Various conventional treatment methods such as coagulation and flotation[1], reverse osmosis[2], reduction and precipitation[3], adsorption[4], ion exchange, membrane technologies and electrolysis[5] have been used so far. Most of these methods are expensive or ineffective especially when the metal concentration is less than $100 \mathrm{ppm}$ [6]. Some generate secondary wastes and toxic sludge that also need other treatments[7].

Biosorption is known as an alternative method for removing heavy metals from soil and water. Metal cations can be absorbed by living and nonliving biomass. Various kinds of biosorbents have been used including: Bacteria[810], yeast[11], fungi[12-14] and algae[15-17]. Bacteria are the most abundant and versatile of microorganisms [biotech] and are used as biosorbents because of their small size, their ubiquity, their ability to grow under controlled conditions, and their resilience to a wide range of environmental situations[18]. Bacteria species such as Bacillus, Pseudomonas, Streptomyces, Escherichia, Micrococcus, etc, have been tested for uptake metals or organics[19]. In literature, there are several reports showing that Bacillus Sp. Is an appropriate sorbent of heavy metal ions. Some studies are listed in table 1.

\footnotetext{
* Corresponding author:

r_marandi@iau-tnb.ac.ir (Reza Marandi)

Published online at http://journal.sapub.org/ijbe

Copyright (C) 2011 Scientific \& Academic Publishing. All Rights Reserved
}

Table 1. Some metal biosorption studies by Bacillus $S p$.

\begin{tabular}{|c|c|c|c|}
\hline Biosorbent & Metal & $\begin{array}{l}\text { Uptake } \\
(\mathrm{mg} / \mathrm{g})\end{array}$ & Reference \\
\hline Bacillus coagulans & \multirow{4}{*}{$\mathrm{Cr}(\mathrm{VI})$} & 39.9 & {$[20]$} \\
\hline Bacillus licheniformis & & 69.4 & [21] \\
\hline Bacillus megaterium & & 30.7 & [22] \\
\hline Bacillus thuringiensis & & 83.3 & [23] \\
\hline Bacillus sp. (ATS-1) & \multirow{2}{*}{$\mathrm{Cu}$} & 16.3 & {$[24]$} \\
\hline Bacillus subtilis IAM 1026 & & 20.8 & [25] \\
\hline Bacillus circulans & $\mathrm{Cd}$ & 26.5 & [23] \\
\hline Bacillus sp. (ATS-1) & $\mathrm{Pb}$ & 92.3 & {$[26]$} \\
\hline Bacillus sp. & $\mathrm{Hg}$ & 7.9 & [27] \\
\hline Bacillus thuringiensis & $\mathrm{Ni}$ & 45.9 & [28] \\
\hline $\begin{array}{c}\text { Bacillus licheniformis IAM } \\
111054\end{array}$ & \multirow{3}{*}{ Th } & 66.1 & \multirow{3}{*}{ [29] } \\
\hline $\begin{array}{c}\text { Bacillus megaterium IAM } \\
1166\end{array}$ & & 74 & \\
\hline Bacillus subtilis IAM 1026 & & 71.9 & \\
\hline $\begin{array}{c}\text { Bacillus licheniformis IAM } \\
111054\end{array}$ & \multirow{3}{*}{$\mathrm{U}$} & 45.9 & \multirow{3}{*}[29]{} \\
\hline $\begin{array}{c}\text { Bacillus megaterium IAM } \\
1166\end{array}$ & & 37.8 & \\
\hline Bacillus subtilis IAM 1026 & & 52.4 & \\
\hline
\end{tabular}

A few biosorption studies have been done on natural wastewater. Hence an investigation seemed to be very useful and mandatory. In this study sorption of $\mathrm{Cu}$ and $\mathrm{Mn}$ ions in wastewater of Sarcheshme copper mine by one of its own organisms, Bacillus thuringiensis was investigated. Being resistant and its compatibility with solute toxic metal ions was the main advantage of using this native microorganism.

Bacillus thuringiensis is an aerobic, Gram-positive, endospore-forming soil bacterium in which during sporulation, produces a parasporal protein toxin called insecticidal crystal protein. These crystals consist of different major protein units with different molecular weights and are generally present in all of the of $B$. 
thuringiensis strains. Since these proteins are toxic to the larvae of dipterans, lepidopteran and coleopteran insects, the bacteria have been used as bioinsecticide worldwide for many years[28].

\section{Materials and Methods}

\subsection{Preparation of the Biosorbent}

Sarcheshme mine's wastewater was transferred to a microbiology lab under sterile condition and Bacillus Thuringiensis was isolated by pour plate method. Bacterial biomass was cultivated in nutrient broth medium using the shake flask method as following. Isolated bacteria were inoculated from nutrient plates to $500 \mathrm{ml}$ Erlenmeyer flasks containing $200 \mathrm{ml}$ growth medium. After inoculation, flasks were shaken at $310^{\circ} \mathrm{K}$ and $100 \mathrm{rpm}$ for 24 hours. In order to deactivate bacteria, flasks were autoclaved at $393^{\circ} \mathrm{K}$, then centrifuged and culture media was discarded. Remaining biomass was dried at $333^{\circ} \mathrm{K}$ oven for 24 hours and then crushed and sieved to obtain homogeneous powder.

\subsection{Wastewater Analysis}

Samples from wastewater were collected 4 times with 2 months intervals. They were analyzed and some solute metal ions detected. Table 2 shows concentration of these metals in the first sample.

In other samples similar concentrations were detected. As seen in table $2 \mathrm{Cu}$ and $\mathrm{Mn}$ had more concentrations than other ions. So their biosorption was investigated in this study. Table 3 shows $\mathrm{Cu}$ and $\mathrm{Mn}$ concentration in all four samples.

\subsection{Biosorption Studies}

In order to optimize effective parameters on metal uptake, batch biosorption experiments were performed. In all steps, $200 \mathrm{ml}$ wastewater containing conical flasks, stirred at 100 rpm using an incubator-shaker. The effects of $\mathrm{pH}$, contact time, biosorbent dose and temperature were examined using the first sample of wastewater with $\mathrm{Cu}$ and $\mathrm{Mn}$ concentration of 5.5 and $8 \mathrm{mg} \cdot \mathrm{l}^{-1}$ respectively. At the end of each experiment the biosorbent was filtered and residual $\mathrm{Cu}$ and $\mathrm{Mn}$ ions in the filtrate were analyzed by an Atomic Absorption Spectrometer. All the experiments were conducted in triplicate and the average of the measurements were used.

Equilibrium uptake (the amount of ion sorbed at equilibrium) was calculated using following equation.

$$
q_{e}=\frac{V\left(C_{i}-C_{e}\right)}{\mathrm{X}}
$$

Where $\mathrm{V}$ is the volume of wastewater (L), $\mathrm{X}$ is the mass of biosorbent $(\mathrm{g}), \mathrm{C}_{\mathrm{i}}$ and $\mathrm{C}_{\mathrm{e}}$ are the initial and equilibrium concentrations of metal ions in aqueous phase (mg. $\left.1^{-1}\right)$ respectively.

\subsubsection{Effect of Contact Time}

To investigate the effect of contact time on $\mathrm{Cu}$ and $\mathrm{Mn}$ biosorption, samples were drawn at pre-determined time intervals and residual ion concentrations were measured. Other sorption parameters were $6,1 \mathrm{~g} .1^{-1}$ and $308^{\circ} \mathrm{K}$ for $\mathrm{pH}$, biosorbent concentration and temperature respectively.

\subsubsection{Effect of Biosorbent Concentration}

Effect of biosorbent concentration on the value of equilibrium uptake $\left(\mathrm{q}_{\mathrm{e}}\right)$, for $\mathrm{Cu}$ and $\mathrm{Mn}$ ions was investigated in the range of 1 to $10 \mathrm{~g}^{-1} \mathrm{l}^{-1}$ at $\mathrm{pH} 6$, temperature $308^{\circ} \mathrm{K}$ and contact time of 180 minutes.

\subsubsection{Effect of $\mathrm{pH}$}

Batch biosorption experiments were done at $\mathrm{pH}$ range of 2-6. It was adjusted using $\mathrm{NaOH} / \mathrm{HCl}$. Biosorbent dose $1 \mathrm{~g} . \mathrm{l}^{-1}$, temperature $308^{\circ} \mathrm{K}$ and contact time 180 minutes.

\subsubsection{Effect of Initial Ion Concentration}

Effect of initial ion concentration on biosorption was investigated by contacting $0.1 \mathrm{~g} . \mathrm{l}^{-1}$ of biosorbent with 4 samples of wastewater. $\mathrm{Cu}$ and $\mathrm{Mn}$ initial concentrations are presented in table 3 . During the experiment $\mathrm{pH}$, contact time, biosorbent dose and temperature were constant values of 6 , 180 minutes, $1 \mathrm{~g} \cdot 1^{-1}$ and $308^{\circ} \mathrm{K}$ respectively.

\subsubsection{Effect Temperature}

Investigating effect of temperature on biosorption was performed at the thermal range of 298 to $318^{\circ} \mathrm{K}$ for a contact time of $180 \mathrm{~min}$, biosorbent dose of $1 \mathrm{gr} . \mathrm{l}^{-1}$ and $\mathrm{pH}$ value of 6 .

Table 2. Metal ion concentrations in the first sample.

\begin{tabular}{|c|c|c|c|c|c|c|c|c|}
\hline Metal ions & $\mathrm{Mo}$ & $\mathrm{Al}$ & $\mathrm{Mn}$ & $\mathrm{Ag}$ & $\mathrm{Ni}$ & $\mathrm{Pb}(\mathrm{II})$ & $\mathrm{Cu}(\mathrm{II})$ & $\mathrm{Fe}(\mathrm{II})$ \\
\hline $\begin{array}{c}\text { Concentrations } \\
\left(\mathrm{mg} . \mathrm{I}^{-1}\right)\end{array}$ & 0.29 & 0.24 & 8 & 0.057 & 0.003 & 0.65 & 5.5 & 0.097 \\
\hline
\end{tabular}

Table 3. $\mathrm{Cu}$ and $\mathrm{Mn}$ ion concentrations in all 4 samples.

\begin{tabular}{|c|c|c|c|c|}
\hline \multirow{2}{*}{ Metal ions } & \multicolumn{4}{|c|}{ Concentrations (mg. l $^{-1}$ ) } \\
\cline { 2 - 5 } & Sample NO. 1 & Sample NO. 2 & Sample NO. 3 & Sample NO. 4 \\
\hline $\mathrm{Cu}$ & 2.25 & 3 & 4.5 & 5.5 \\
\hline
\end{tabular}




\subsubsection{Sorption-Desorption Studies}

Sorption- desorption experiments were conducted by taking $200 \mathrm{ml}$ of wastewater on to $0.1 \mathrm{~g}$ of the sorbent in following conditions; $\mathrm{pH}=6$, temperature $108{ }^{\circ} \mathrm{K}$, stirring time was 180 minutes at $100 \mathrm{rpm}$. Then it was filtered and residual $\mathrm{Cu}$ and $\mathrm{Mn}$ ion concentrations in filtrate were measured. Metal loaded biosorbent was shaken at $108{ }^{\circ} \mathrm{K}$ with $100 \mathrm{ml}$ of $1 \mathrm{M} \mathrm{HCL}$ for 30 minutes. Then eluted biomass was extracted and washed with generous amounts of deionized water till neutrality. $\mathrm{HCl}$ was analyzed for $\mathrm{Cu}$ and $\mathrm{Mn}$ ions. Another 4 sorption -desorption cycles were done to investigate reusability of the bacterial sorbent.

\section{Results and Discussion}

\subsection{Effect of Contact Time}

Fig. 1 shows the effect of contact time on $\mathrm{Cu}$ and $\mathrm{Mn}$ uptake by the bacteria. It is seen that the sorption capacity of the sorbent increased with an increase in time for both metals.

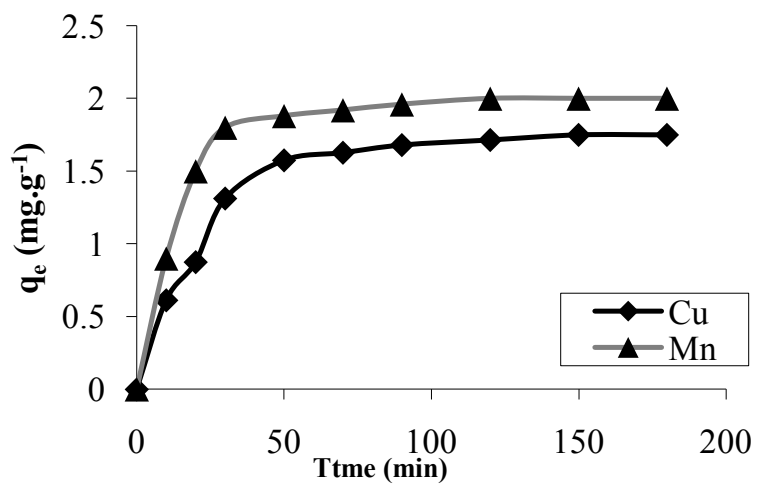

Figure 1. The effect of contact time on biosorption of $\mathrm{Cu}$ and $\mathrm{Mn}$ ions.

The amount of $\mathrm{Cu}$ and $\mathrm{Mn}$ ions sorbed per unit mass of sorbent increased sharply up to 30 minutes and then slowed gradually. This probably is due to the availability of active metal binding sites at the beginning of the experiment. After 50 minutes metal uptake became very slow for both metal ions and equilibrium reached after 120 and 150 minutes for $\mathrm{Mn}$ and $\mathrm{Cu}$ respectively. Equilibrium time for $\mathrm{Cu}$ was more due to its lower concentration in waste water.

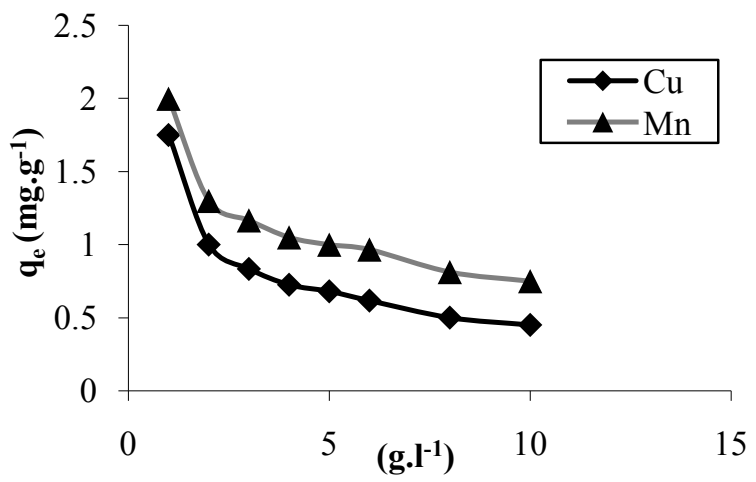

Figure 2. The effect of biosorbent concentration on biosorption of $\mathrm{Cu}$ and Mn ions.

\subsection{Effect of Biosorbent Concentration}

By increasing biosorbent dosage, ion uptake per unit weight of the sorbent $\left(\mathrm{q}_{\mathrm{e}}\right)$, was decreased for both metals (fig. 2). Increasing biosorbent dosage may result in more biosorbent surface area and more available adsorption sites. These sites remain unsaturated during biosorption process so equilibrium uptake decreases by increasing biosorbent dose[30].

\subsection{Effect of $\mathbf{p H}$}

Among factors influencing biosorption, $\mathrm{pH}$ strongly determines the speciation and biosorption availability of the metal ions and seems to affect the solution chemistry of metals and the activity of functional groups of the biomass $[31,32]$. The charge of the adsorbate and adsorbent often depend on $\mathrm{pH}$ of the solution.

In literature during the biosorption of metal ions by bacterial biomass pH 3 to 6 has been found favorable for biosorption due to the negatively charged carboxyl groups which are responsible for the binding metal cations via ion exchange mechanisms[33].

The effect of wastewater $\mathrm{pH}$ on biosorption is shown in fig. 2. The low metal uptake under $\mathrm{pH} 3$ is due to high concentration of hydrogen ions and competition for binding to the active sites by metal ions and $\mathrm{H}^{+}$in the wastewater.

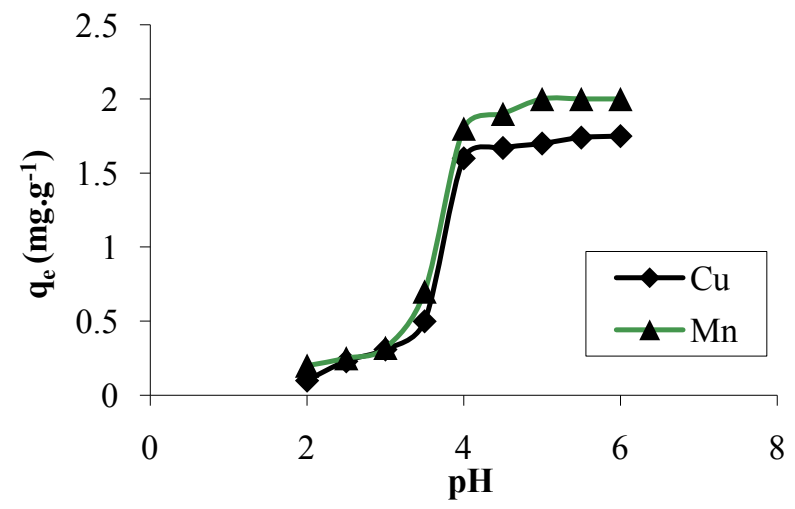

Figure 3. The effect of wastewater $\mathrm{pH}$ on biosorption of $\mathrm{Cu}$ and $\mathrm{Mn}$ ions

Metal uptake increased very sharply with an increase in $\mathrm{pH}$ from 3 to 4 but it did not change significantly beyond $\mathrm{pH}$ 4.5. Increasing metal uptake at higher $\mathrm{pH}$ values may be attributed to the negative charged on the cell wall and ionic states of ligands[34]. Gram positive bacteria have anionic polymers in their cell wall structure which mainly consist of peptidoglycan, teichoic or teichuronic acids [35-36].

Maximum uptake was achieved at $\mathrm{pH} 6$ so it was determined as optimum value for both metals. Similar result has been reported for Nickel removal by Bacillus thuringiensis[29].

The experiment was not run at higher $\mathrm{pH}$ values due to possible hydrolysis and precipitation.

\subsection{Effect of Initial Ion Concentration in Wastewater}

The initial ion concentration plays an important role in biosorption. Figs. (3 to 4 ) exhibit that the equilibrium uptake 
increased by increasing initial ion concentrations for both $\mathrm{Cu}$ and $\mathrm{Mn}$ ions. Higher amounts of metal ions in wastewater increased the contact probabibility between these ions and active binding sites on the surface of the biosorbent and subsequently enhanced the metal removal.

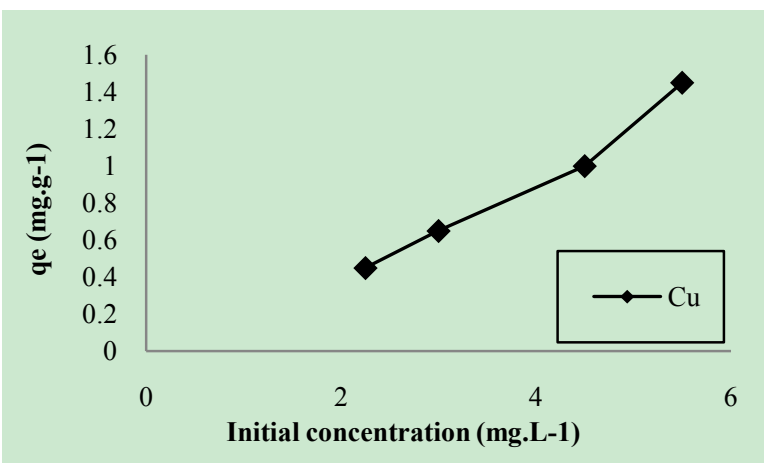

Figure 4. The effect of initial ion concentrations on biosorption of $\mathrm{Cu}$.

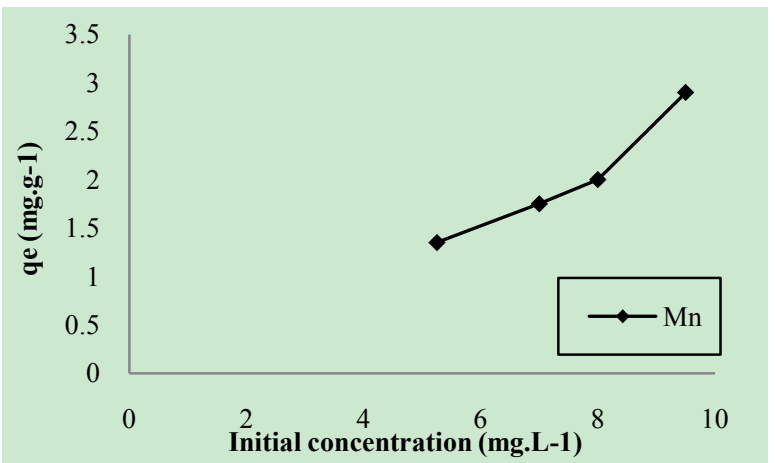

Figure 5. The effect of initial ion concentrations on biosorption of Mn.

In order to understand the biosorption mechanism and surface behavior of the biosorbent and examine the relationship between sorbed and aqueous concentration at equilibrium, two-parameter equilibrium models: Langmuir[37] and Freundlich[38] were used.

Langmuir model which is valid for modeling monolayer adsorption on to a homogeneous surface is shown as following:

$$
q_{e}=\frac{q_{\max } \cdot b_{L} \cdot C_{e}}{1+b_{L} \cdot C_{e}}
$$

Two constants in this classical model are $\mathrm{q}_{\max }\left(\mathrm{mg} \cdot \mathrm{g}^{-1}\right)$, the maximum amount of metal uptake and $b_{\mathrm{L}}$, which is related to the affinity between sorbate and sorbent binding sites $\left(1 . \mathrm{mg}^{-1}\right) \cdot \mathrm{C}_{\mathrm{e}}$ is the equilibrium metal concentration in aqueous phase (mg. $\left.\mathrm{g}^{-1}\right)$.

This equation can be described by the linear form:

$$
\frac{1}{q_{e}}=\left(\frac{1}{c_{e}} \cdot \frac{1}{b_{L} \cdot q_{\max }}\right)+\frac{1}{q_{\max }}
$$

$b_{\mathrm{L}}$ and $\mathrm{q}_{\max }$ can be determined by plotting $1 / \mathrm{q}_{\mathrm{e}}$ vs. $1 / \mathrm{C}_{\mathrm{e}}$. For a good biosorbent, high $\mathrm{q}_{\max }$ and $\mathrm{b}_{\mathrm{L}}$ are generally desirable[39].

The Freundlich isotherm which assumes that the uptake occurs on a heterogeneous adsorbent surface can be expressed by:

$$
q_{e}=K_{F} \cdot C_{e}^{1 / n_{F}}
$$

Where $\mathrm{K}_{\mathrm{F}}$ and $\mathrm{n}_{\mathrm{F}}$ are Freundlich constants related to the capacity and intensity of the sorbent respectively. By taking logarithms, equation (3) changes to:

$$
\log q_{e}=\frac{1}{n} \log C_{e}+\log K_{F}
$$

Freundlich constants can be achieved from slope and intercept of plot $\log \mathrm{q}_{\mathrm{e}}$ as a function of $\log \mathrm{C}_{\mathrm{e}}$. These isotherms were applied to data from 4 different initial ion concentrations at $308^{\circ} \mathrm{K}, \mathrm{pH}: 6$, contact time 180 minutes and biosorbent concentration of 1 g. $1^{-1}$ (figs. 3 to 5). Parameters related to Langmuir and Freundlich isotherms are presented in table 3 .

The correlation coefficients $\left(\mathrm{r}^{2}\right)$ were high for both isotherms but as seen the Langmuir isotherm describes the process better. Also the higher concentration of $\mathrm{Mn}$ ions in the wastewater may be the main cause of comparatively higher $r^{2}$ values for Mn.

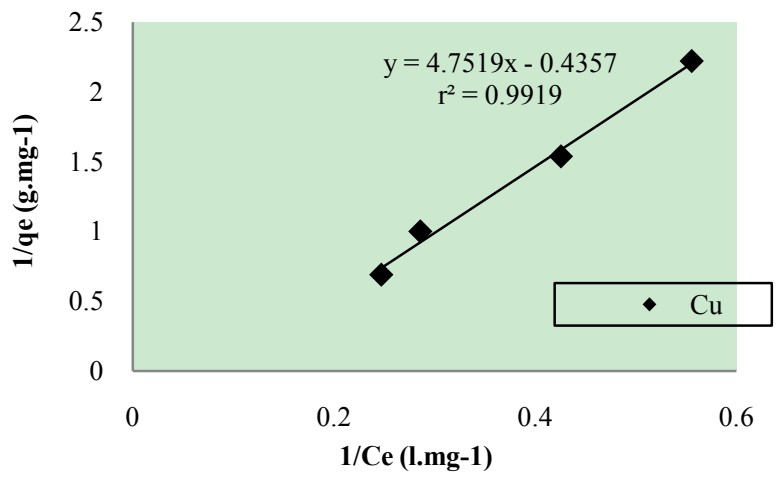

Figure 6. Cu sorption isotherms based on the Langmuir model.

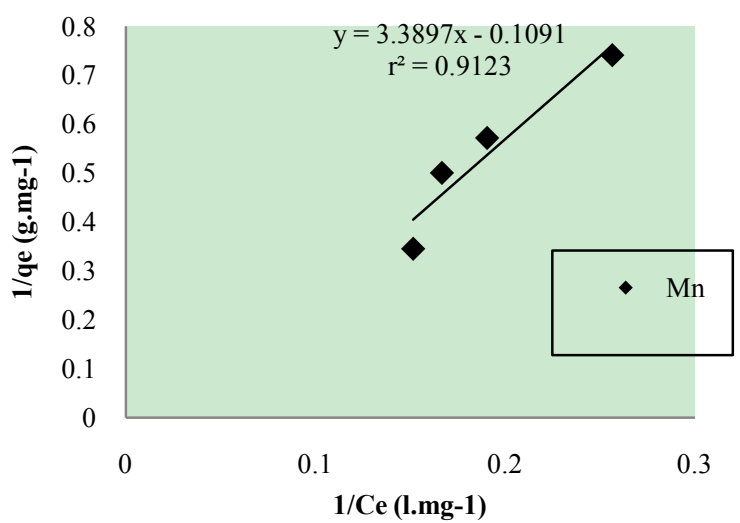

Figure 7. Mn sorption isotherms based on the Langmuir model.

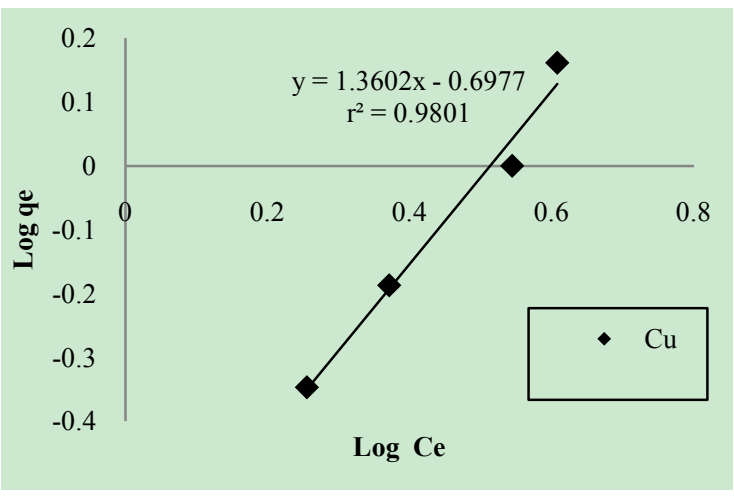

Figure 8. Cu sorption isotherms based on the Freundlich model. 
Table 4. Langmuir and Freundlich biosorption isotherms.

\begin{tabular}{|c|c|c|c|c|c|c|c|}
\hline Isotherms & \multicolumn{3}{|c|}{ Freundlich } & \multicolumn{4}{c|}{ Langmuir } \\
\hline Parameters & $\mathrm{r}^{2}$ & $\begin{array}{c}\mathrm{q}_{\max } \\
\left(\mathrm{mg} . \mathrm{g}^{-1}\right)\end{array}$ & $\begin{array}{c}\mathrm{K}_{\mathrm{L}} \\
\left(\mathrm{L}_{\mathrm{mg}}\right)^{-1}\end{array}$ & $\mathrm{R}_{\mathrm{L}}$ & $\mathrm{r}^{2}$ & $\mathrm{n}$ & $\mathrm{K}_{\mathrm{F}}$ \\
\hline $\mathrm{Cu}$ & 0.9919 & 2.29 & 0.092 & 0.664 & 0.9801 & 0.73 & 4.98 \\
\hline $\mathrm{Mn}$ & 0.9123 & 9.17 & 0.032 & 0.85 & 0.8714 & 0.77 & 4.56 \\
\hline
\end{tabular}

Table 5. Sorption-desorption efficiencies of $\mathrm{cu}$ and $\mathrm{Mn}$ ions on bacterial biomass.

\begin{tabular}{|c|c|c|c|c|c|c|c|c|c|c|}
\hline Metal & & & $\mathbf{C u}$ & & & & & Mn & & \\
\hline Number of cycles & 1 & 2 & 3 & 4 & 5 & 1 & 2 & 3 & 4 & 5 \\
\hline Metal ion sorption $\left(\mathrm{mg} \cdot \mathrm{g}^{-1}\right)$ & 1.75 & 1.69 & 1.65 & 1.6 & 1.54 & 2 & 1.96 & 1.91 & 1.86 & 1.79 \\
\hline Metal ion desorption $\left(\mathrm{mg} \cdot \mathrm{g}^{-1}\right)$ & 1.72 & 1.65 & 1.6 & 1.54 & 1.47 & 1.99 & 1.91 & 1.88 & 1.78 & 1.71 \\
\hline Desorption Efficiency (\%) & 98.3 & 97.6 & 97 & 96.3 & 95.5 & 99.5 & 97.4 & 98.4 & 95.7 & 95.5 \\
\hline Sorption Efficiency (\%) & _ & 96.6 & 97.6 & 97 & 96.3 & - & 98 & 97.4 & 97.4 & 96.2 \\
\hline
\end{tabular}

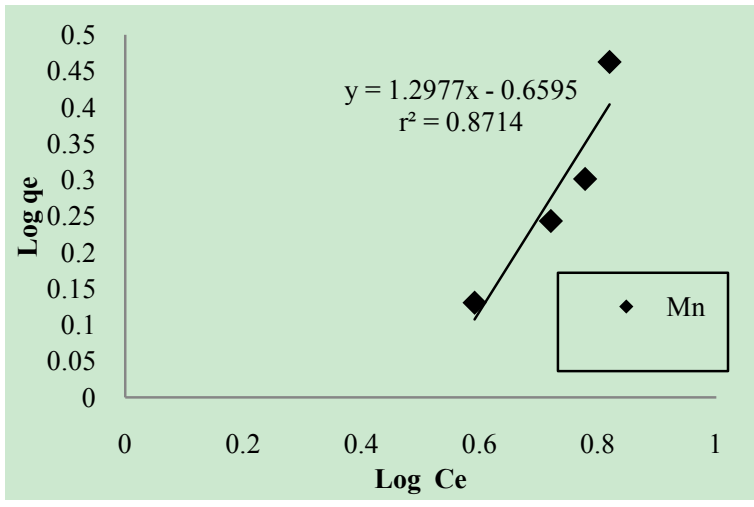

Figure 9. Mn sorption isotherms based on the Freundlich model.

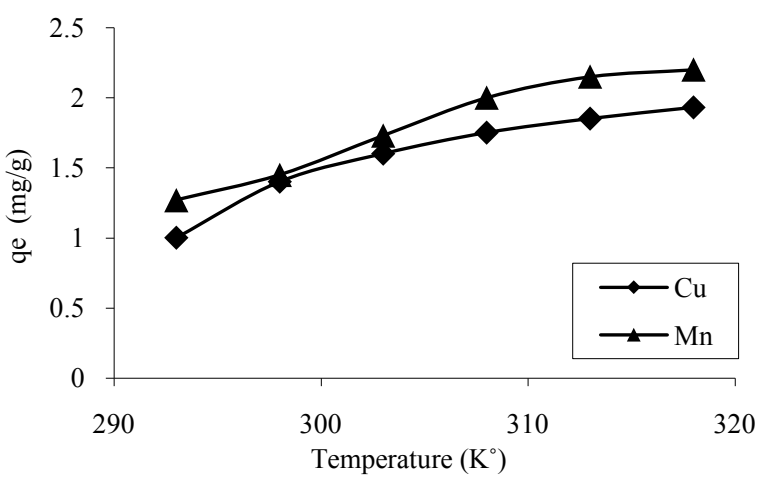

Figure 10. The effect of temperature on biosorption.

To determine favorability of $\mathrm{Cu}$ and $\mathrm{Mn}$ uptake by Bacillus Thuringiensis, a dimensionless separation factor, $\mathrm{R}_{\mathrm{L}}$, was determined[40].

$$
R_{L}=\frac{1}{1+b_{L} \cdot C_{0}}
$$

$\mathrm{b}_{\mathrm{L}}$ is the Langmuir isotherm constant $\left(1 . \mathrm{mg}^{-1}\right)$ and $\mathrm{C}_{0}$ is the initial $\mathrm{Cu}$ and $\mathrm{Mn}$ concentrations in wastewater $\left(\mathrm{mg} \cdot \mathrm{l}^{-1}\right)$. According to Eq. 5 when $0<\mathrm{R}_{\mathrm{L}}<1$ biosorption process is favorable, $R_{L}>1$ it is unfavorable and $R_{L}=1$ indicates a linear isotherm. As seen in table 4 the adsorption is favorable for both metals. Since the initial concentration of $\mathrm{Mn}$ is higher it's uptake is more favorable than $\mathrm{Cu}$.

\subsection{Effect of Temperature}

High temperatures usually enhance sorption due to the increased surface activity and kinetic energy of the solute [41-43]. But in some cases high temperature may cause damage of active binding sites on the biosorbent surface.

As seen in fig. 6 an increase in the temperature from 293 to $318^{\circ} \mathrm{K}$ led to an increase from 1 to $1.93 \mathrm{mg} . \mathrm{g}^{-1}$ and 1.27 to 2.2 mg. ${ }^{-1}$ for $\mathrm{Cu}$ and $\mathrm{Mn}$ ions respectively. Maximum equilibrium uptake occurred at $318^{\circ} \mathrm{K}$ for both metals. This proved that the adsorption of $\mathrm{Cu}$ and $\mathrm{Mn}$ ions to bacterial biomass was controlled by an endothermic process. As mentioned rising metal uptake capacity was the result of increasing collision frequency between metal ions and the biosorbent active sites.

\subsection{Sorption-Desorption Studies}

Sorption-desorption results are summarized in table 5. As seen both metal ion sorbed and metal ion desorbed decreased from cycle 1 to 5 . Strong sorbent-sorbate affinity may be the main cause of difference between amount of sorbed and desorbed ions. Although sorption-desorption efficiencies decreased they were high in all cycles for both $\mathrm{Cu}$ and $\mathrm{Mn}$ ions.

\section{Conclusions}

In the study of removing $\mathrm{Cu}$ and $\mathrm{Mn}$ ions by Bacillus Thuringiensis following conclusions were drawn:

1. Using native microorganisms can be very effective due to their high resistance and compatibility to the environment.

2. The natural biomass of Bacillus Thuringiensis that isolated from Sarcheshme mine's wastewater can be consider as a very effective and low cost sorbent for the purpose of mine's effluent treatment.

3. Finding and optimizing effective parameters on batch mode operation was very important to achieve high sorption capacity. 
4. Biosorption was very fast at first and $75 \%$ and $90 \%$ of total $\mathrm{Cu}$ And $\mathrm{Mn}$ uptake occurred after first 30 minutes.

5. The adsorption equilibrium data were fitted well both Langmuir and Freundlich isotherm models, but Langmuir isotherm gave the better fit.

6 . The biosorption capacity increased with increasing temperature up to $320^{\circ} \mathrm{K}$.

7. In five consecutive cycles biosorbed metal ions were easily eluted using $1 \mathrm{M} \mathrm{HCl}$ and the biomass was regenerated and reused with high sorption/desorption efficiency.

\section{REFERENCE}

[1] Zouboulis, A.I., Matis, K.A., Lanara, B.G. and Loos-Neskovic, C., 1997, Removal of cadmium from dilute solutions by hydroxyapatite. II. Floatation studies. Sep Sci Technol, 32(10):1755-1767

[2] Ahmady-Asbchin S., Yves A., Ge`rente C., Le Cloirec P. (2008) "Biosorption of $\mathrm{Cu}$ (II) from aqueous solution by Fucus serratus:Surface characterization and sorption mechanisms" J. of. Biores. Technol., 99, (2008), pp 6150-6155

[3] Esalah, O.J., Weber, M.E. and Vera, J.H., 2000, Removal of lead, cadmium and zinc from aqueous solutions by precipitation with sodium di-(n-octyl) phosphinate. Can J Chem Eng, 78:948-954

[4] Ravindran, V., Stevens, M.R., Badriyha, B.N. and Pirbazari, M., 1999, Modeling the sorption of toxic metals on chelant-impregnated adsorbent. AIChE J, 45(5):1135-1146

[5] Canet, L., Ilpide, M. and Seta, P., 2002, Efficient facilitated transport of lead, cadmium, zinc and silver across a flat sheet-supported liquid membrane mediated by lasalocid A. Sep Sci Technol, 37(8): 1851-1860

[6] Schiewer, S. and Volesky, B., 1995, Modeling of the proton-metal ion exchange in iosorption. Environ Sci Technol, 29:3029-3058

[7] Kapoor A., Viraraghavan T., Cullimore D. R. (1999) "Removal of heavy metals using the fungus Aspergillus niger”, J. of. Biores. Technol., 70, (1999), pp 95-104

[8] T. Srinath, T. Verma, P.W. Ramteke, S.K. Garg, Chromium (VI) biosorption and bioaccumulation by chromate resistant bacteria, Chemosphere 48 (2002) 427-435

[9] S. Tunali, A. C, abuk, T. Akar, Removal of lead and copper ions from aqueous solutions by bacterial strain isolated fromsoil, Chem. Eng. J. 115 (2006) 203-211

[10] A. Iyer, K. Mody, B. Jha, Biosorption of heavy metals by amarine bacterium,Mar. Pollut. Bull. 50 (2005) 340-343

[11] Padmavathy V. (2007) "Biosorption of nickel(II) ions by baker's yeast: Kinetic, thermodynamic and desorption studies" J. of. Biores. Technol., 99, (2008), pp 3100-3109

[12] G. Yan, T. Viraraghavan, Heavy-metal removal from aqueous solution by fungus Mucor rouxii,Water Res. 37 (2003) 4486-4496
[13] S. Tunali, T. Akar, Zn(II) biosorption properties of Botrytis cinerea biomass, J. Hazard. Mater. 131 (2006) 137-145

[14] T. Akar, S. Tunali, Biosorption characteristics of Aspergillus flavus biomass for removal of $\mathrm{Pb}(\mathrm{II})$ and $\mathrm{Cu}(\mathrm{II})$ ions from an aqueous solution, Bioresour. Technol. 97 (2006) 1780-1787

[15] A. Sari, M. Tuzen, Biosorption of $\mathrm{Pb}(\mathrm{II})$ and $\mathrm{Cd}(\mathrm{II})$ from aqueous solution using green alga (Ulva lactuca), J. Hazard. Mater. 152 (2008) 302-308

[16] K. Chojnacka, A. Chojnacki, H. Górecka, Biosorption of $\mathrm{Cr} 3+, \mathrm{Cd} 2+$ and $\mathrm{Cu} 2+$ ions by blue-green algae Spirulina sp.: kinetics, equilibrium and the mechanism of the process, Chemosphere 59 (2005) 75-84

[17] P. Lodeiro, B. Cordero, J.L. Barriada, R. Herrero, M.E. Sastre de Vicente, Biosorption of cadmium by biomass of brown marine macroalgae, Bioresour. Technol. 96 (2005) 17961803.

[18] Mann H. Removal and recovery of heavy metals by biosorption. In: Volesky B, editor. Biosorption of heavy metals. Boca Raton: CRC press; 1990. p. 93-137

[19] Urrutia MM. General Bacterial Sorption Processes. In: Wase J, Forster C, editors. Biosorbents for metal ions. London, UK: CRC Press; 1997. p. 39-66

[20] Jianlog W., Biosorbents for heavy metals removal and their future, Biotechnology Advances 27 (2009) 195-226

[21] Srinath T., Verma T., Ramteke PW., Garg SK. (2002) "Chromium (VI) biosorption and bioaccumulation by chromate resistant bacteria" J. of. Chemosphere., 48, 2002, pp 427-35

[22] Zhou M, Liu Y, Zeng G, Li X, XuW, Fan T. Kinetic and equilibrium studies of $\mathrm{Cr}$ (VI) biosorption by dead Bacillus licheniformis biomass. World J Microbiol Biotechnol 2007;23:43-8

[23] Şahin Y, Öztürk A. Biosorption of chromium(VI) ions from aqueous solution by the bacterium Bacillus thuringiensis. Process Biochem 2005;40:1895-901

[24] Tunali S, Çabuk A, Akar T. Removal of lead and copper ions from aqueous solutions by bacterial strain isolated from soil. Chem Eng J 2006;115:203-11

[25] Nakajima A, Yasuda M, Yokoyama H, Ohya-Nishiguchi H, Kamada H. Copper biosorption by chemically treated Micrococcus luteus cells.World JMicrobiol Biotechnol $2001 ; 17: 343-7$

[26] Yilmaz EI, Ensari NY. Cadmium biosorption by Bacillus circulans strain EB1. World J Microbiol Biotechnol 2005;21:777-9

[27] Green-Ruiz C. Mercury(II) removal from aqueous solutions by nonviable Bacillus sp. from a tropical estuary. Biores Technol 2006;97:1907-11

[28] Öztürk A. Removal of nickel from aqueous solution by the bacterium Bacillus thuringiensis. J Hazard Mater 2007; 147:518-23

[29] Nakajima A, Tsuruta T. Competitive biosorption of thorium and uranium by Micrococcus luteus. J Radioanal Nucl Chem 2004;260:13-8 
[30] E. Schnepf, N. Crickmore, J. Van Rie, D. Lereclus, J. Baum, J. Feitelson, D.R. Zeigler, D.H. Dean, Bacillus thuringiensis and its pesticidal crystal proteins, Microbiol. Mol. Biol. Rev. 62 (3) (1998) 775-806

[31] W.H. Zou, R.P. Han, Z.Z. Chen, J. Shi, H.M. Liu, Characterization and Properties of manganese oxide coated zeolite (MOCZ) as adsorbent for removal of copper(II) and lead(II) ions from solution, J. Chem. Eng. Data 51 (2006) 534-541

[32] Yang J, Volesky B. Modeling the uranium-proton ion exchange in biosorption. Environ Sci Technol 1999b; $33: 4079-85$

[33] Esposito A, Pagnanelli F, Vegliò F. pH-related equilibria models for biosorption in single metal systems. Chem Eng Sci 2002;57:307-13

[34] Vijayaraghavan K, Yun YS. Bacterial biosorbents and biosorption. Biotechnol Adv 2008;26:266-91

[35] Volesky B. (2007) “Biosorption and me” J. of. Water Res., 41, (2007), pp 4017-4029

[36] I.C. Hancock, The use of Gram-positive bacteria for the removal of metals from aqueous solution, in: R. Thompson (Ed.), Trace Metal removal from Aqueous Solution, Royal
Soc. Chem., London, 1986, p. 25 (Spec. Publ. 61)

[37] M.N. Hughes, R.K. Poole, Removal or recovery of metal ions and compounds from solution by microbiological methods, in: Metals and Microorganisms, Chapman and Hall, London, 1989 , p. 328

[38] Langmuir I. The adsorption of gases on plane surfaces of glass, mica and platinum. J Am Chem Soc 1918; 40: 1361403

[39] Freundlich H. Ueber die adsorption in loesungen. Z Phys Chem 1907; 57: 385-470

[40] Kratochvil D, Volesky B. Advances in the biosorption of heavy metals. TIBTECH 1998; 16: 291-300

[41] Weber, T.W., Chakraborti, R.K., 1974. Pore and Solid diffusion models for fixed bed adsorbers. J. Am. Inst. Chem. Eng. 20, 228-232

[42] Sağ Y, Kutsal T. Determination of the biosorption heats of heavy metal ions on Zoogloea ramigera and Rhizopus arrhizus. Biochem Eng J 2000; 6: 145-51

[43] Vijayaraghavan K, Yun YS. Utilization of fermentation waste (Corynebacterium glutamicum) for biosorption of Reactive Black 5 from aqueous solution. J Hazard Mater 2007b; 141: $45-52$ 